\title{
Association between the polymorphisms of the vascular endothelial growth factor gene and metabolic syndrome
}

\author{
YOUNG REE KIM ${ }^{1}$ and SEUNG-HO HONG ${ }^{2}$ \\ ${ }^{1}$ Department of Laboratory Medicine, School of Medicine, Jeju National University, Jeju 690-756; \\ ${ }^{2}$ Department of Science Education, Teachers College, Jeju National University, Jeju 690-781, Republic of Korea
}

Received December 1, 2014; Accepted January 27, 2015

DOI: 10.3892/br.2015.423

\begin{abstract}
Vascular endothelial growth factor (VEGF) is a major angiogenic factor. Increased levels of VEGF have been reported in patients with metabolic syndrome (MetS). The role of $V E G F$ polymorphisms in MetS susceptibility, however, has not been reported previously. Thus, the present study was performed to analyze the associations between the $V E G F-634 \mathrm{G}>\mathrm{C}$ and $936 \mathrm{C}>\mathrm{T}$ polymorphisms and the patients with MetS. A total of 320 patients with MetS (mean age, $49.86 \pm 11.76$ years) and 320 healthy subjects (mean age, $50.94 \pm 8.43$ years) were enrolled in the study. The $V E G F-634 \mathrm{G}>\mathrm{C}$ polymorphism in the 5'-untranslated region (UTR) and $936 \mathrm{C}>\mathrm{T}$ polymorphism in 3'-UTR were analyzed by polymerase chain reaction-restriction fragment length polymorphism. The $V E G F-634 \mathrm{G}>\mathrm{C}$ polymorphism significantly affected MetS susceptibility. The CC genotype of the $-634 \mathrm{G}>\mathrm{C}$ polymorphism was significantly associated with an increased risk of MetS [adjusted odds ratio $(\mathrm{AOR})=3.973 ; 95 \%$ confidence interval $(\mathrm{CI}), 2.321-6.799$; $\mathrm{P}<0.0001]$. AORs of the dominant (GG vs. GC+CC) and recessive models ( $\mathrm{GG}+\mathrm{GC}$ vs. $\mathrm{CC}$ ) between the cases and controls were 2.569 (95\% CI, 1.657-3.983; $\mathrm{P}<0.0001)$ and 2.163 (95\% CI, 1.475-3.171; $\mathrm{P}=0.0001)$, respectively. Haplotypes of $-634 \mathrm{G}>\mathrm{C}$ and $936 \mathrm{C}>\mathrm{T}$ were also associated with MetS susceptibility. When the haplotype data were stratified by gender, the association remained only in males. The $-634 \mathrm{G}>\mathrm{C}$ polymorphism was also associated with the subgroups of MetS risk components by the stratification analysis. The $936 \mathrm{C}>\mathrm{T}$ polymorphism was, however, not associated with the MetS susceptibility. The present study demonstrates that the VEGF $-634 \mathrm{G}>\mathrm{C}$ polymorphism and haplotypes may be a genetic determinant for the MetS susceptibility. To the best of our knowledge, this is the first study on the significant
\end{abstract}

Correspondence to: Professor Seung-Ho Hong, Department of Science Education, Teachers College, Jeju National University, 61 Iljudong-ro, Jeju-si, Jeju Special Self-Governing Province, Jeju 690-781, Republic of Korea

E-mail: shong@jejunu.ac.kr

Key words: metabolic syndrome, polymorphism, VEGF association of the $V E G F$ polymorphisms in MetS patients. To confirm the effects of the VEGF polymorphisms on MetS, further functional and population studies are required.

\section{Introduction}

Metabolic syndrome (MetS) is characterized by possessing three or more abnormal traits among the risk factors of triglycerides (TG), high-density lipoprotein (HDL)-cholesterol, blood pressure, glucose and waist circumferences (WC). Although the definition and mechanisms underlying MetS are unclear, MetS is a multifactorial disorder, in which genetic and environmental factors, including diet and life style, play a major role (1). The prevalence of MetS may be different among ethnicities.

Vascular endothelial growth factor (VEGF), a potent angiogenic factor, is a main regulatory protein of endothelial cell proliferation. The human VEGF gene has been mapped to chromosome $6 \mathrm{p} 21.3$ and the clones have been isolated and sequenced. The gene is composed of eight exons spanning $\sim 14 \mathrm{~kb}$ of DNA (2). The overexpression of $V E G F$ has been observed in a variety of tissues, including the female reproductive system, ischemic tissues, tumors and transformed cell lines (3). VEGF functions mainly through binding to different membrane-bound receptors, such as VEGF receptor-1 (VEGF-R1), VEGF-R2 and VEGF-receptor-3 (4-6). VEGF-induced vascular permeability and angiogenesis can be caused by the alternative splicing of the $V E G F$ gene $(7,8)$.

Inter-individual variations in the VEGF plasma levels have been reported (9). Increased levels of VEGF have been observed in patients with MetS (10). Plasma VEGF levels were significantly associated with the components of MetS, such as body mass index (BMI), WC, blood pressure and inflammation $(11,12)$. Decreased plasma levels of nitric oxide and VEGF in the patients with MetS may result in significant endothelial dysfunction (13). Soluble VEGF-R2 is increased in the sera of the subjects with MetS in association with insulin resistance (14).

Several mutations have been described in the $V E G F$ gene. The $-2578 \mathrm{CC}$ genotype of the $-2578 \mathrm{C}>\mathrm{A}$ polymorphism and $-634 \mathrm{CC}$ genotype of the $-634 \mathrm{G}>\mathrm{C}$ polymorphism are associated with a higher VEGF production compared to the other genotypes (15-18), whereas the $936 \mathrm{~T}$ allele of the $936 \mathrm{C}>\mathrm{T}$ polymorphism correlates with lower VEGF plasma levels 
than the 936C allele $(19,20) . V E G F$ polymorphisms have been associated with several human diseases based on a putative angiogenic factor. In particular, the genetic defects of $V E G F$ could be associated with risk factors of MetS, such as vascular diseases or diabetic retinopathy (DR) $(15,16,21-27)$, although the results are not always consistent in all the populations studied.

Therefore, based on the current biological and pathological significance of VEGF known, it is reasonable to hypothesize that VEGF may be a good candidate in determining the risk of the MetS pathogenesis. However, to the best of our knowledge, the effects of VEGF polymorphisms on MetS susceptibility have not been evaluated previously. To test this hypothesis, the possible associations between the VEGF -634G >C (rs2010963) and 936C $>\mathrm{T}$ (rs3025039) polymorphisms and the patients with MetS were investigated.

\section{Materials and methods}

Study population. A total of 320 MetS patients (mean age, $49.86 \pm 1.76$ years) and 320 healthy controls (mean age, $50.94 \pm 8.43$ years) were recruited from Jeju, South Korea. The diagnosis of the MetS patients was based upon individuals with three or more traits among the five risk factors according to the National Cholesterol Education Program (28) Adult Treatment Panel III definition for MetS with slight modifications. The control group was selected following health screening to exclude those with a history of chest pain, diabetes, hypertension and general illness. Informed consent for all the study subjects was obtained. The study was approved by the Institutional Review Board of Jeju National University Hospital (Jeju, South Korea). The biospecimens and data used in the study were provided by the Biobank of Jeju National University Hospital, a member of the Korea Biobank Network, supported by the Ministry of Health and Welfare.

DNA extraction and amplification. Total genomic DNA was prepared from whole blood following the lysis of red blood cells. The areas spanning the polymorphic sites of $-634 \mathrm{G}>\mathrm{C}$ in the 5'-untranslated region (UTR) and $936 \mathrm{C}>\mathrm{T}$ in the 3 '-UTR of the $V E G F$ gene were amplified by the polymerase chain reaction from the genomic DNA using primers and reaction conditions described previously (24). The $-634 \mathrm{G}>\mathrm{C}$ and 936C $>$ T polymorphisms were identified following the digestion of amplified DNA with the endonucleases, AvaII and NlaIII, respectively. Briefly, for the $-634 \mathrm{G}>\mathrm{C}$ polymorphism, the size of the amplicon was 204 base pairs (bp). The $-634 \mathrm{G}$ allele was cut into two fragments of 180 and $24 \mathrm{bp}$, whereas the $-634 \mathrm{C}$ allele remained uncut. Alleles of the $936 \mathrm{C}>\mathrm{T}$ polymorphic site were classified depending on the presence ( $\mathrm{T}$ allele, 122 and $86 \mathrm{bp}$ ) or absence (C allele, $208 \mathrm{bp}$ ) of a restriction enzyme cutting site.

Phenotype measurements. For the measurements of biochemical concentrations, blood was collected from the study subjects into a tube containing anticoagulant following overnight fasting. The levels of plasma fasting blood sugar (FBS) by the hexokinase-G-6-phosphate dehydrogenase method (Wako, Tokyo, Japan) and TG and HDL-cholesterol by enzymatic colorimetric methods (Kyowa Medex Co., Ltd.,
Table I. Comparisons of the demographic characteristics between the controls and MetS patients.

\begin{tabular}{lccr}
\hline Characteristic & Control & MetS patients & P-value $^{\mathrm{a}}$ \\
\hline Subjects, $\mathrm{n}$ & 320 & 320 & \\
Age, years & $50.94 \pm 8.43$ & $49.86 \pm 11.76$ & 0.183 \\
BMI, kg/m & $23.87 \pm 2.715$ & $27.40 \pm 2.65$ & $<0.001$ \\
FBS, mg/dl & $87.35 \pm 10.09$ & $104.41 \pm 26.67$ & $<0.001$ \\
TG, mg/dl & $86.53 \pm 39.57$ & $211.89 \pm 170.81$ & $<0.001$ \\
HDL-cholesterol, & $57.01 \pm 13.57$ & $44.44 \pm 10.41$ & $<0.001$ \\
mg/dl & & & \\
SBP, mmHg & $117.99 \pm 12.03$ & $133.61 \pm 14.53$ & $<0.001$ \\
DBP, mmHg & $70.84 \pm 8.53$ & $81.95 \pm 10.43$ & $<0.001$ \\
WC, cm & $72.07 \pm 9.160$ & $85.38 \pm 10.28$ & $<0.001$ \\
\hline
\end{tabular}

Data are mean \pm standard deviation. ${ }^{2} \chi^{2}$ test for categorical data, two-sided t-test for continuous data. MetS, metabolic syndrome; BMI, body mass index; FBS, fasting blood sugar; TG, triglyceride; HDL-cholesterol, high-density lipoprotein cholesterol; SBP, systolic blood pressure; DBP, diastolic blood pressure; WC, waist circumference.

Tokyo, Japan) adapted to an automated analyzer TBA-200FR Neo (Toshiba Medical Systems Co., Ltd., Tokyo, Japan) were determined.

The anthropometric parameters containing BMI and WC were measured. The BMI was calculated as the weight in kilograms divided by the square of the height in meters. With a flexible tape, WC was measured at the smallest horizontal circumference between the costal margin and iliac crest. Blood pressures were measured using a standard sphygmomanometer on the right arm at a seated position after $10 \mathrm{~min}$ of rest.

The MetS patients had significantly higher values $(\mathrm{P}<0.001)$ for all the conventional risk factors containing BMI, TG, systolic blood pressure (SBP), diastolic blood pressure (DBP) and WC, but lower HDL-cholesterol levels $(\mathrm{P}<0.001)$ compared to the controls (Table I).

Statistical analysis. The student's t-test was used to compare the demographic characteristics between the patients and controls. The $\chi^{2}$ test was used for the categorical variables to analyze baseline characteristics. The $\chi^{2}$ test was also used for comparing the frequencies of the $V E G F$ polymorphisms between the controls and cases. Allele frequencies were calculated by the gene counting method to identify deviations from the Hardy-Weinberg equilibrium. The associations among the MetS and VEGF genotypes were estimated by computing the odd ratios and $95 \%$ confidence intervals (95\% CIs) using the Fisher's exact test. The adjusted odds ratios (AORs) for the $V E G F$ polymorphisms were determined from multiple logistic regression using age and gender. StatsDirect statistical software (Version 2.4.4; StatsDirect Ltd, Altrincham, UK) was used to calculate the AOR and 95\% CI. The stratification analysis was used to assess the MetS risk components. $\mathrm{P}<0.05$ was considered to indicate a statistically significant difference. Haplotype frequencies for multiple loci were estimated using the expectation-maximization algorithm with SNPAlyze (Version 5.1; Dynacom Co., Ltd., Yokohama, Japan). 
Table II. Genotype frequencies of the $V E G F-634 \mathrm{G}>\mathrm{C}$ and $936 \mathrm{C}>\mathrm{T}$ polymorphisms between the control subjects and MetS patients.

\begin{tabular}{|c|c|c|c|c|}
\hline Genotype & Controls $(n=320)$ & $\operatorname{MetS}(n=320)$ & $\operatorname{AOR}(95 \% \mathrm{CI})$ & P-value ${ }^{a}$ \\
\hline \multicolumn{5}{|l|}{$V E G F-634 \mathrm{G}>\mathrm{C}$} \\
\hline GG & $85(26.5)$ & $39(12.2)$ & 1.000 (reference) & \\
\hline $\mathrm{GC}$ & $172(53.8)$ & $172(53.8)$ & $2.124(1.352-3.336)$ & $0.001^{\mathrm{b}}$ \\
\hline $\mathrm{CC}$ & $63(19.7)$ & $109(34.0)$ & $3.973(2.321-6.799)$ & $<0.0001^{\mathrm{b}}$ \\
\hline $\mathrm{GG}$ vs. $\mathrm{GC}+\mathrm{CC}$ & & & $2.569(1.657-3.983)$ & $<0.0001^{\mathrm{b}}$ \\
\hline $\mathrm{GG}+\mathrm{GC}$ vs. $\mathrm{CC}$ & & & $2.163(1.475-3.171)$ & $0.0001^{\mathrm{b}}$ \\
\hline \multicolumn{5}{|l|}{$V E G F 936 \mathrm{C}>\mathrm{T}$} \\
\hline $\mathrm{CC}$ & $216(67.5)$ & $196(61.3)$ & 1.000 (reference) & \\
\hline $\mathrm{CT}$ & $89(27.8)$ & $99(30.9)$ & $1.321(0.914-1.910)$ & 0.139 \\
\hline TT & $15(4.7)$ & $25(7.8)$ & $1.985(0.975-4.039)$ & 0.059 \\
\hline CC vs. CT+TT & & & $1.414(1.000-1.998)$ & 0.050 \\
\hline $\mathrm{CC}+\mathrm{CT}$ vs. TT & & & $1.811(0.898-3.651)$ & 0.097 \\
\hline
\end{tabular}

${ }^{a}$ Adjusted by age and gender; ${ }^{b}$ significant difference. $V E G F$, vascular endothelial growth factor; MetS, metabolic syndrome; AOR, adjusted odds ratio; CI, confidence interval.

Table III. Genotype frequencies of the VEGF polymorphisms between the controls and patients with MetS according to gender.

\begin{tabular}{|c|c|c|c|c|c|c|c|c|}
\hline \multirow[b]{2}{*}{ Genotype } & \multicolumn{4}{|c|}{ Male } & \multicolumn{4}{|c|}{ Female } \\
\hline & $\begin{array}{l}\text { Controls } \\
(n=152)\end{array}$ & $\begin{array}{c}\text { MetS } \\
(n=254)\end{array}$ & OR $(95 \% \mathrm{CI})$ & P-value ${ }^{a}$ & $\begin{array}{l}\text { Controls } \\
(n=168)\end{array}$ & $\begin{array}{c}\text { MetS } \\
(n=66)\end{array}$ & OR $(95 \%$ CI $)$ & P-value ${ }^{a}$ \\
\hline \multicolumn{9}{|l|}{$V E G F-634 \mathrm{G}>\mathrm{C}$} \\
\hline GG & $39(25.7)$ & $31(12.2)$ & 1.000 (reference) & & $46(27.4)$ & $8(12.1)$ & 1.000 (reference) & \\
\hline $\mathrm{GC}$ & $88(57.9)$ & $133(52.4)$ & $1.925(1.108-3.342)$ & $0.020^{\mathrm{b}}$ & $84(50.0)$ & $39(59.1)$ & $2.444(1.040-5.744)$ & $0.040^{\mathrm{b}}$ \\
\hline $\mathrm{CC}$ & $25(16.4)$ & $90(35.4)$ & $4.809(2.483-9.311)$ & $<0.0001^{\mathrm{b}}$ & $38(22.6)$ & $19(28.8)$ & $2.641(1.025-6.806)$ & $0.044^{\mathrm{b}}$ \\
\hline GG vs. $\mathrm{GC}+\mathrm{CC}$ & & & $2.540(1.496-4.310)$ & $0.001^{\mathrm{b}}$ & & & $2.521(1.107-5.741)$ & $0.028^{\mathrm{b}}$ \\
\hline $\mathrm{GG}+\mathrm{GC}$ vs. $\mathrm{CC}$ & & & $2.950(1.776-4.902)$ & $<0.0001^{\mathrm{b}}$ & & & $1.350(0.700-2.605)$ & 0.371 \\
\hline \multicolumn{9}{|l|}{$V E G F 936 \mathrm{C}>\mathrm{T}$} \\
\hline $\mathrm{CC}$ & $107(70.4)$ & $158(62.2)$ & 1.000 (reference) & & $109(64.9)$ & $38(57.6)$ & 1.000 (reference) & \\
\hline $\mathrm{CT}$ & $38(25.0)$ & $77(30.3)$ & $1.357(0.854-2.156)$ & 0.196 & $51(30.3)$ & $22(33.3)$ & $1.251(0.665-2.356)$ & 0.488 \\
\hline $\mathrm{TT}$ & $7(4.6)$ & $19(7.5)$ & $2.045(0.808-5.175)$ & 0.131 & $8(4.8)$ & $6(9.1)$ & $2.148(0.661-6.980)$ & 0.204 \\
\hline CC vs. CT+TT & & & $1.447(0.937-2.235)$ & 0.096 & & & $1.370(0.757-2.482)$ & 0.299 \\
\hline $\mathrm{CC}+\mathrm{CT}$ vs. TT & & & $1.797(0.727-4.442)$ & 0.204 & & & $1.978(0.364-6.176)$ & 0.240 \\
\hline
\end{tabular}

${ }^{a}$ Adjusted by age and gender; ${ }^{b}$ significant difference. $V E G F$, vascular endothelial growth factor; MetS, metabolic syndrome; AOR, adjusted odds ratio; CI, confidence interval.

\section{Results}

Genotype frequencies. The genotype frequencies of the $V E G F-634 \mathrm{G}>\mathrm{C}$ and $936 \mathrm{C}>\mathrm{T}$ polymorphisms between MetS and control groups are shown in Table II. The genotype distributions for two polymorphic loci were not deviated significantly from the Hardy-Weinberg equilibrium for the two groups.

The GC and CC genotype frequencies for the GG genotype of the $-634 \mathrm{G}>\mathrm{C}$ polymorphism were significantly associated with an increased risk of MetS susceptibility $(\mathrm{AOR}=2.124 ; 95 \% \mathrm{CI}, 1.352-3.336 ; \mathrm{P}=0.001$; and $\mathrm{AOR}=3.973$;
95\% CI, 2.321-6.799; $\mathrm{P}<0.0001$, respectively). The dominant $(\mathrm{GG}$ vs. $\mathrm{GC}+\mathrm{CC})$ and recessive $(\mathrm{GG}+\mathrm{GC}$ vs. CC) models of the $-634 \mathrm{G}>\mathrm{C}$ polymorphism were also significantly different between the MetS patients and controls (AOR=2.569; 95\% CI, 1.657-3.983; $\mathrm{P}<0.0001$; and $\mathrm{AOR}=2.163$; $95 \%$ CI, $1.475-3.171 ; \mathrm{P}=0.001$, respectively). In practice, the $\mathrm{C}$ allele frequency (0.609) of the MetS patients was significantly higher than that of the controls (0.466). When the MetS and control subjects were subgrouped according to the gender, the association remained as almost the same pattern with total subjects in males and females (Table III). By contrast, the TT genotype and dominant model (CC vs. CT+TT) 
Table IV. Comparison of the haplotype frequencies of the $V E G F-634 \mathrm{G}>\mathrm{C}$ and $936 \mathrm{C}>\mathrm{T}$ polymorphisms between control subjects and patients with MetS.

\begin{tabular}{lcccc}
\hline Haplotype & Controls $(2 \mathrm{n}=640, \%)$ & MetS $(2 \mathrm{n}=640, \%)$ & OR $(95 \% \mathrm{CI})$ & P-value $^{\mathrm{a}}$ \\
\hline$-634 \mathrm{G}>\mathrm{C} / 936 \mathrm{C}>\mathrm{T}$ & & & & \\
G-C & $279(43.6)$ & $192(30.0)$ & $0.555(0.441-0.698)$ & $<0.0001^{\mathrm{b}}$ \\
G-T & $63(9.8)$ & $58(9.1)$ & $0.913(0.627-1.328)$ & 0.703 \\
C-C & $242(37.8)$ & $299(46.7)$ & $1.442(1.154-1.802)$ & $0.002^{\mathrm{b}}$ \\
C-T & $56(8.8)$ & $91(14.2)$ & $1.729(1.215-2.460)$ & $0.003^{\mathrm{b}}$ \\
\hline
\end{tabular}

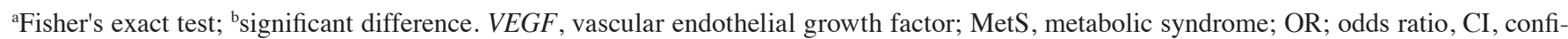
dence interval.

Table V. Genotype frequencies of the VEGF polymorphisms between the controls and patients with MetS according to gender.

\begin{tabular}{|c|c|c|c|c|c|c|c|c|}
\hline \multirow[b]{2}{*}{ Haplotype } & \multicolumn{4}{|c|}{ Male } & \multicolumn{4}{|c|}{ Female } \\
\hline & $\begin{array}{l}\text { Controls } \\
(2 n=304)\end{array}$ & $\begin{array}{c}\text { MetS } \\
(2 n=508)\end{array}$ & OR $(95 \% \mathrm{CI})$ & P-value ${ }^{a}$ & $\begin{array}{l}\text { Controls } \\
(2 n=336)\end{array}$ & $\begin{array}{c}\text { MetS } \\
(2 n=132)\end{array}$ & OR $(95 \% \mathrm{CI})$ & P-value \\
\hline \multicolumn{9}{|c|}{$-634 \mathrm{G}>\mathrm{C} / 936 \mathrm{C}>\mathrm{T}$} \\
\hline G-C & $132(43.4)$ & $148(29.1)$ & $0.536(0.398-0.721)$ & $<0.0001^{\mathrm{b}}$ & $147(43.8)$ & $45(34.1)$ & $0.665(0.437-1.012)$ & 0.061 \\
\hline G-T & $34(11.2)$ & $46(9.1)$ & $0.810(0.508-1.291)$ & 0.398 & $29(8.6)$ & $10(7.6)$ & $0.868(0.410-1.835)$ & 0.853 \\
\hline $\mathrm{C}-\mathrm{C}$ & $120(39.5)$ & $246(48.4)$ & $1.440(1.079-1.921)$ & $0.013^{\mathrm{b}}$ & $122(36.3)$ & $53(40.1)$ & $1.177(0.779-1.779)$ & 0.459 \\
\hline C-T & $18(5.9)$ & $68(13.4)$ & $2.456(1.430-4.216)$ & $0.001^{\mathrm{b}}$ & $38(11.3)$ & $24(18.2)$ & $1.743(0.999-3.040)$ & 0.068 \\
\hline
\end{tabular}

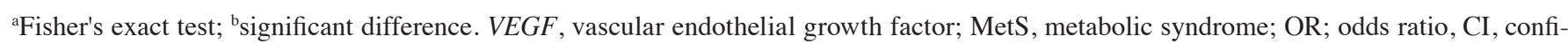
dence interval.

frequencies of the $936 \mathrm{C}>\mathrm{T}$ polymorphism were higher in the MetS patients compared to the controls $(\mathrm{P}=0.059$ and $\mathrm{P}=0.05$, respectively), although they were not statistically significant. No significant difference was detected when the data of the 936C $>\mathrm{T}$ polymorphism were stratified by the gender.

Haplotype frequencies. The haplotype frequencies of the $V E G F-634 \mathrm{G}>\mathrm{C}$ and $936 \mathrm{C}>\mathrm{T}$ polymorphisms were compared between the MetS patients and control groups (Table IV). The C-C and C-T haplotypes of the $-634 \mathrm{G}>\mathrm{C}$ and $936 \mathrm{C}>\mathrm{T}$ polymorphisms were associated with increased MetS susceptibility, whereas the G-C haplotype was significantly lower in the MetS patients compared to the controls. When the haplotype data were stratified by the gender, the association remained in the male group only (Table V).

Stratification analysis for the risk components. Table VI lists the stratification analysis for risk components of MetS in the $-634 \mathrm{G}>\mathrm{C}$ polymorphism. The $-634 \mathrm{GC}+\mathrm{CC}$ for the -634GG genotype was associated with increased MetS susceptibility for three components [BMI $\geq 25$; glucose $\geq 110$; $\mathrm{TG} \geq 150$; and HDL-cholesterol $<40$ (male) and $<50$ (female)]. However, other components [HDL-cholesterol, $\geq 40$ (male) and $\geq 50$ (female); SBP <135; DBP <85; and WC $<90$ (male) and $<85$ (female)] were associated with decreased MetS susceptibility. By contrast, the 936CT+TT frequency for $936 \mathrm{CC}$ in the $936 \mathrm{C}>\mathrm{T}$ polymorphism was associated with decreased MetS susceptibility only in the blood pressure (SBP $<135$ and DBP $<85$ ) by the stratification analysis (data not shown).

\section{Discussion}

VEGF, a major angiogenic factor, is involved in the regulation of endothelial cell proliferation. Thus, the potential role of VEGF has attracted considerable interest. Thus far, several single-nucleotide polymorphisms (SNPs) have been described in the $V E G F$ gene. Certain SNPs are associated with a susceptibility to several disorders; however, the results are not always consistent in all the studied populations.

Although the causes of MetS development are unclear, it is a multifactorial disease that occurs following a complex interaction between genetic factors that are largely unknown and environmental factors, such as lifestyle and dietary habits. The patients with MetS are associated with increased levels of VEGF (10). Therefore, it is possible to hypothesize the involvement of VEGF in the MetS pathogenesis. In spite of the association studies of $V E G F$ polymorphisms with several diseases, to the best of our knowledge, the effect of $V E G F$ polymorphisms on the risk of MetS has not been evaluated. Therefore, the association between the $-634 \mathrm{G}>$ polymorphism in the 5'-UTR and 936C $>$ T polymorphism in the 3'-UTR of the $V E G F$ gene and the patients with the MetS was analyzed as a case-control study. 
Table VI. Genotype frequencies of the $V E G F-634 \mathrm{G}>\mathrm{C}$ polymorphism according to variables.

\begin{tabular}{|c|c|c|c|c|c|}
\hline Variables & $V E G F-634 \mathrm{G}>\mathrm{C}$ & Control $(n=320)$ & $\operatorname{MetS}(n=320)$ & AOR $(95 \% \mathrm{CI})$ & P-value ${ }^{a}$ \\
\hline \multicolumn{6}{|l|}{$\mathrm{BMI}, \mathrm{kg} / \mathrm{m}^{2}$} \\
\hline$\geq 25$ & $\begin{array}{c}634 \mathrm{GG} \\
634 \mathrm{GC}+\mathrm{CC}\end{array}$ & $\begin{array}{l}30(9.4) \\
74(23.1)\end{array}$ & $\begin{array}{r}32(10.0) \\
234(73.1)\end{array}$ & $\begin{array}{l}1.000(\text { reference }) \\
3.042(1.715-5.397)\end{array}$ & $0.0001^{\mathrm{b}}$ \\
\hline$<25$ & $\begin{array}{c}634 \mathrm{GG} \\
634 \mathrm{GC}+\mathrm{CC}\end{array}$ & $\begin{array}{r}55(17.2) \\
161(50.3)\end{array}$ & $\begin{array}{c}7(2.2) \\
47(14.7)\end{array}$ & $\begin{array}{l}1.000 \text { (reference) } \\
1.968(0.799-4.846)\end{array}$ & 0.141 \\
\hline \multicolumn{6}{|l|}{$\mathrm{FBS}, \mathrm{mg} / \mathrm{dl}$} \\
\hline$\geq 110$ & $\begin{array}{c}634 \mathrm{GG} \\
634 \mathrm{GC}+\mathrm{CC}\end{array}$ & $\begin{array}{l}3(0.9) \\
5(1.6)\end{array}$ & $\begin{array}{c}6(1.9) \\
74(23.1)\end{array}$ & $\begin{array}{l}1.000 \text { (reference) } \\
9.738(1.348-70.36)\end{array}$ & $0.024^{\mathrm{b}}$ \\
\hline$<110$ & $\begin{array}{c}634 \mathrm{GG} \\
634 \mathrm{GC}+\mathrm{CC}\end{array}$ & $\begin{array}{r}82(25.6) \\
230(71.9)\end{array}$ & $\begin{array}{r}33(10.3) \\
207(64.7)\end{array}$ & $\begin{array}{l}1.000(\text { reference }) \\
2.165(1.356-3.456)\end{array}$ & $0.001^{\mathrm{b}}$ \\
\hline \multicolumn{6}{|l|}{$\mathrm{TG}, \mathrm{mg} / \mathrm{dl}$} \\
\hline$\geq 150$ & $\begin{array}{c}634 \mathrm{GG} \\
634 \mathrm{GC}+\mathrm{CC}\end{array}$ & $\begin{array}{r}7(2.2) \\
19(5.9)\end{array}$ & $\begin{array}{c}27(8.4) \\
198(61.9)\end{array}$ & $\begin{array}{l}1.000 \text { (reference) } \\
2.821(1.080-7.370)\end{array}$ & $0.034^{\mathrm{b}}$ \\
\hline$<150$ & $\begin{array}{c}634 \mathrm{GG} \\
634 \mathrm{GC}+\mathrm{CC}\end{array}$ & $\begin{array}{r}78(24.4) \\
216(67.5)\end{array}$ & $\begin{array}{l}12(3.8) \\
80(25.0)\end{array}$ & $\begin{array}{l}1.000 \text { (reference) } \\
2.244(1.135-4.440)\end{array}$ & $0.020^{\mathrm{b}}$ \\
\hline \multicolumn{6}{|l|}{ HDL-cholesterol, mg/dl } \\
\hline$<40$, male, $<50$, female & $\begin{array}{c}634 \mathrm{GG} \\
634 \mathrm{GC}+\mathrm{CC}\end{array}$ & $\begin{array}{l}13(4.1) \\
32(10.0)\end{array}$ & $\begin{array}{c}20(6.3) \\
137(42.8)\end{array}$ & $\begin{array}{l}1.000 \text { (reference) } \\
2.773(1.248-6.161)\end{array}$ & $0.012^{\mathrm{b}}$ \\
\hline$\geq 40$, male, $\geq 50$, female & $\begin{array}{c}634 \mathrm{GG} \\
634 \mathrm{GC}+\mathrm{CC}\end{array}$ & $\begin{array}{r}72(22.5) \\
203(63.4)\end{array}$ & $\begin{array}{c}19(5.9) \\
144(45.0)\end{array}$ & $\begin{array}{l}1.000 \text { (reference) } \\
2.749(1.584-4.769)\end{array}$ & $0.0003^{b}$ \\
\hline \multicolumn{6}{|l|}{$\mathrm{SBP}, \mathrm{mmHg}$} \\
\hline$\geq 135$ & $\begin{array}{c}634 \mathrm{GG} \\
634 \mathrm{GC}+\mathrm{CC}\end{array}$ & $\begin{array}{r}5(1.6) \\
21(6.5)\end{array}$ & $\begin{array}{c}22(6.9) \\
117(36.6)\end{array}$ & $\begin{array}{l}1.000 \text { (reference) } \\
1.261(0.415-3.833)\end{array}$ & 0.683 \\
\hline$<135$ & $\begin{array}{c}634 \mathrm{GG} \\
634 \mathrm{GC}+\mathrm{CC}\end{array}$ & $\begin{array}{r}80(25.0) \\
214(66.9)\end{array}$ & $\begin{array}{c}17(5.3) \\
164(51.2)\end{array}$ & $\begin{array}{l}1.000 \text { (reference) } \\
3.615(2.016-6.480)\end{array}$ & $<0.0001^{\mathrm{b}}$ \\
\hline \multicolumn{6}{|l|}{$\mathrm{DBP}, \mathrm{mmHg}$} \\
\hline$\geq 85$ & $\begin{array}{c}634 \mathrm{GG} \\
634 \mathrm{GC}+\mathrm{CC}\end{array}$ & $\begin{array}{r}3(0.9) \\
15(4.7)\end{array}$ & $\begin{array}{c}13(4.1) \\
101(31.6)\end{array}$ & $\begin{array}{l}1.000(\text { reference }) \\
1.843(0.413-8.224)\end{array}$ & 0.423 \\
\hline$<85$ & $\begin{array}{c}634 \mathrm{GG} \\
634 \mathrm{GC}+\mathrm{CC}\end{array}$ & $\begin{array}{r}82(25.6) \\
220(68.8)\end{array}$ & $\begin{array}{c}26(8.1) \\
180(56.2)\end{array}$ & $\begin{array}{l}1.000 \text { (reference) } \\
2.495(1.513-4.116)\end{array}$ & $0.0003^{\mathrm{b}}$ \\
\hline \multicolumn{6}{|l|}{$\mathrm{WC}, \mathrm{cm}$} \\
\hline$\geq 90$, male,$\geq 85$, female & $634 \mathrm{GG}$ & $3(0.9)$ & $25(7.8)$ & 1.000 (reference) & \\
\hline & $634 \mathrm{GC}+\mathrm{CC}$ & $13(4.1)$ & $124(38.7)$ & $1.123(0.289-4.361)$ & 0.867 \\
\hline$<90$, male, $<85$, female & $\begin{array}{c}634 \mathrm{GG} \\
634 \mathrm{GC}+\mathrm{CC}\end{array}$ & $\begin{array}{r}82(25.6) \\
222(69.4)\end{array}$ & $\begin{array}{c}14(4.4) \\
157(49.1)\end{array}$ & $\begin{array}{l}1.000(\text { reference }) \\
4.176(2.284-7.634)\end{array}$ & $<0.0001^{\mathrm{b}}$ \\
\hline
\end{tabular}

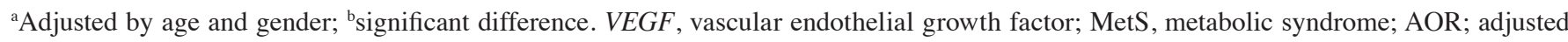
odds ratio, CI, confidence interval; BMI, body mass index; FBS, fasting blood sugar; TG, triglycerides; HDL-cholesterol, high density lipoprotein cholesterol; SBP, systolic blood pressure; DBP, diastolic blood pressure; WC, waist circumference.

In the present study, the $\mathrm{CC}$ genotype and $\mathrm{C}$ allele frequencies of the $V E G F-634 \mathrm{G}>\mathrm{C}$ polymorphism were associated with significantly increased MetS susceptibility in the Korean population. MetS is associated with an increased risk of metabolic or vascular disorders, such as diabetes, atherosclerosis and cardiovascular events. Previous studies have reported that the $-634 \mathrm{G}>\mathrm{C}$ polymorphism is associated with a susceptibility to disorders, such as DR in the subjects with type 2 diabetes, coronary artery disease (CAD) and acute myocardial infarction (AMI). The CC genotype or C allele of the VEGF-634G $>$ C polymorphism is associated with increased DR susceptibility in type 2 diabetes $(16,22,29,30)$. By a meta-analysis, Qiu et al (31) confirmed the association between the $-634 \mathrm{G}>\mathrm{C}$ polymorphism and DR in the subjects with type 2 diabetes. The CC genotype was also associated with an impaired prognosis in the patients with chronic heart failure (21), the development of heart failure following myocardial infarction (23), AMI (15) and coronary collaterals in the patients with CAD (26) and coronary atherosclerosis (25). The -634 variant genotypes (GC and CC) in the patients with silent brain infarction were significantly lower than those in the controls (24), whereas the G allele of $-634 \mathrm{G}>\mathrm{C}$ polymorphism was significantly higher in the patients with Kawasaki disease with coronary artery lesions (CAL) than in those without CAL or control subjects (32). Moradzadegan et al (33) reported 
that the $-634 \mathrm{G}$ allele can be an independent risk factor for the susceptibility of CAD in Iranian type II diabetic patients. The $-634 \mathrm{CC}$ or GG genotype is associated with different stages of peripheral arterial disease (PAD) in the diabetic patients (34). The GG genotype in the $-634 \mathrm{G}>\mathrm{C}$ polymorphism is independently associated with the development of a diabetic nephropathy population (35). Although Petrovic et al (36) did not identify the genetic susceptibility to proliferative diabetic retinopathy for the $-634 \mathrm{G}>\mathrm{C}$ polymorphism, significantly higher serum levels of VEGF were demonstrated in DR with the CC genotype compared to those with the other $(\mathrm{CG}+\mathrm{GG})$ genotypes.

By contrast, several studies reported that the associations were not between the $-634 \mathrm{G}>\mathrm{C}$ polymorphism and the diseases For example, the $-634 \mathrm{G}>\mathrm{C}$ polymorphism was not associated with DR $(37,38)$, the risk of cardiovascular disease in patients with rheumatoid arthritis (39), intima-media thickness and the risk of AMI (40), coronary atherosclerosis patients (41), vasculitis (42) and susceptibility of conotruncal heart defects (27). The influence of the $-634 \mathrm{G}>\mathrm{C}$ polymorphism on the risk for MetS, to the best of our knowledge, has not been reported. Therefore, the present data requires confirmation as an association between the $-634 \mathrm{G}>\mathrm{C}$ polymorphism and MetS patients of various ethnicities with larger sample numbers.

In the present study, the $\mathrm{C}-\mathrm{C}$ and $\mathrm{C}-\mathrm{T}$ haplotypes of the $-634 \mathrm{G}>\mathrm{C}$ and $936 \mathrm{C}>\mathrm{T}$ polymorphisms were associated with increased MetS susceptibility, indicating that there could be a linkage disequilibrium (LD) between the $-634 \mathrm{G}>\mathrm{C}$ and 936C $>\mathrm{T}$ polymorphisms, or these mutations may have LD with another functional mutation elsewhere in the VEGF gene sequence, thereby causing differences between individuals in the production of the VEGF protein. Kim et al (24) reported strong LDs between loci $-1154 \mathrm{G}>\mathrm{A}$ and $-634 \mathrm{G}>\mathrm{C}$, and $-2578 \mathrm{C}>\mathrm{A}$ and $-634 \mathrm{G}>\mathrm{C}$ in the ischemic stroke patients, and $-2578 \mathrm{C}>\mathrm{A}$ and $-634 \mathrm{G}>\mathrm{C}$ of the $V E G F$ gene in the patients with silent brain infarction. Several studies reported that the haplotypes of the $V E G F$ polymorphisms can affect the susceptibility of the diseases. The C-A-G and C-A-C haplotypes of the $V E G F-2578 \mathrm{C}>\mathrm{A},-1154 \mathrm{G}>\mathrm{A}$ and $-634 \mathrm{G}>\mathrm{C}$ polymorphisms were also more common in the African-American compared to the Caucasian population, indicating interethnic disparities in the susceptibility to cardiovascular diseases (43). The $-2578 \mathrm{~A}>\mathrm{C},-634 \mathrm{G}>\mathrm{C}$ and $936 \mathrm{C}>\mathrm{T}$ variations in the $V E G F$ gene are weakly associated with intima-media thickness and the risk of AMI, but the effect can only be observed when the information of the SNPs is combined by constructing haplotypes (40).

Healthy subjects with the CC genotype of the $-634 \mathrm{G}>\mathrm{C}$ polymorphism have significantly higher VEGF levels than those with the other genotypes (18). The levels of plasma VEGF could not be estimated; therefore, whether the $-634 \mathrm{G}>\mathrm{C}$ polymorphism of the $V E G F$ gene was associated with the clinical components of MetS was examined by the stratification analysis (Table IV). The $-634 \mathrm{GC}+\mathrm{CC}$ frequency for -634GG was associated with increased MetS susceptibility for abnormality values of BMI $(\mathrm{P}=0.0001)$, FBS $(\mathrm{P}=0.024)$, TG $(\mathrm{P}=0.034)$ and HDL-cholesterol $(\mathrm{P}=0.012)$. Although the mechanism is currently unknown, one possible hypothesis is that the VEGF protein could be correlated with the MetS risk factors. Plasma VEGF levels were significantly associated with the components of MetS, such as BMI, WC, blood pressure and inflammation $(11,12)$. Sandhofer et al (44) also reported that plasma VEGF and VEGF-R1 is correlated with cardiovascular risk factors in Austrian healthy subjects. VEGF expression could be fluctuated with an interaction between VEGF and VEGF receptors, and by the alternative splicing of the $V E G F$ gene $(7,8)$. Another possibility is that VEGF levels could be altered by its gene expression. In practice, the VEGF expression could be increased at the transcriptional and translational levels by $-634 \mathrm{G}>\mathrm{C}$ substitution (45). Stevens et al (46) reported that subjects with the $-460 \mathrm{C} /+405 \mathrm{G}$ haplotype of the $V E G F-460 \mathrm{C}>\mathrm{T}$ and $+405 \mathrm{G} / \mathrm{C}$ (also known as $-634 \mathrm{G}>\mathrm{C}$ ) polymorphisms had an increased $V E G F$ promoter activity. The $-634 \mathrm{G}>\mathrm{C}$ locus is located in a potential binding site of the myeloid zinc finger-1 transcription factor of the 5'-UTR.

In the light of the genetic heterogeneity, MetS may develop from the joint effect of the $V E G F$ gene with other genes associated with the MetS development. Recently, Strauss et al (47) reported that VEGF -634C allele carriers were associated with an increased risk for the development of the abdominal aortic aneurysm (AAA) without coexisting PAD, or risk independently of PAD coexistence. The risk was enhanced by the interaction of the $-634 \mathrm{CC}$ homozygotes with $1772 \mathrm{CC}$ and 1790GG genotypes of the hypoxia-induced factor-1 $\alpha$ (HIF1A) gene $1772 \mathrm{C}>\mathrm{T}$ and $1790 \mathrm{G}>\mathrm{A}$ polymorphisms. By contrast, the interaction of the $-634 \mathrm{GG}$ homozygotes with the $1772 \mathrm{~T}$ allele of the HIF1A $1772 \mathrm{C}>$ T polymorphism and $1772 \mathrm{~T}-1790 \mathrm{G}$ haplotype were significantly associated with the occurrence of AAA with concomitant PAD for the dominant model. Therefore, it is extremely difficult to explain only with $V E G F$ polymorphisms due to the genetic heterogeneity, such as MetS.

The present study demonstrates that, at least in the Korean population, the $-634 \mathrm{G}>\mathrm{C}$ polymorphism and haplotypes of the $V E G F$ gene may be the risk factors for MetS susceptibility. This is the first study regarding the association between the $V E G F$ polymorphisms and patients with MetS. The data add further evidence to the concept of a polygenic etiological background of MetS. However, the role of VEGF and VEGF SNPs in the pathogenesis of MetS is uncertain and remains to be determined. Therefore, further evaluation is necessary to explore the associations between the VEGF polymorphisms and MetS using larger samples in various ethnic populations. Functional studies are also required to confirm the role of VEGF or VEGF SNPs in MetS.

\section{Acknowledgements}

The present study was supported by the Basic Science Research Program through the National Research Foundation of Korea (NRF), funded by the Ministry of Education, Science and Technology (grant no. NRF-2012R1A1A4A01012216).

\section{References}

1. Eberly LE, Prineas R, Cohen JD, Vazquez G, Zhi X, Neaton JD and Kuller LH and Multiple Risk Factor Intervention Trial Research Group: Metabolic syndrome: Risk factor distribution and 18-year mortality in the multiple risk factor intervention trial. Diabetes Care 29: 123-130, 2006.

2. Tischer E, Mitchell R, Hartman T, Silva M, Gospodarowicz D, Fiddes JC and Abraham JA: The human gene for vascular endothelial growth factor. Multiple protein forms are encoded through alternative exon splicing. J Biol Chem 266: 11947-11954, 1991. 
3. Iruela-Arispe ML and Dvorak HF: Angiogenesis: A dynamic balance of stimulators and inhibitors. Thromb Haemost 78: 672-677, 1997.

4. Ferrara N, Gerber HP and LeCouter J: The biology of VEGF and its receptors. Nat Med 9: 669-676, 2003.

5. Ruhrberg C: Growing and shaping the vascular tree: Multiple roles for VEGF. BioEssays 25: 1052-1060, 2003.

6. Tammela T, Zarkada G, Wallgard E, et al: Blocking VEGFR-3 suppresses angiogenic sprouting and vascular network formation. Nature 454: 656-660, 2008

7. Konopatskaya O, Churchill AJ, Harper SJ, Bates DO and Gardiner TA: VEGF165b, an endogenous C-terminal splice variant of VEGF, inhibits retinal neovascularization in mice. Mol Vis 12: 626-632, 2006.

8. Shen WY, Lai CM, Graham CE, Binz N, Lai YK, Eade J, Guidolin D, Ribatti D, Dunlop SA and Rakoczy PE: Long-term global retinal microvascular changes in a transgenic vascular endothelial growth factor mouse model. Diabetologia 49: $1690-1701,2006$

9. Renner W and Pilger E: Simultaneous in vivo quantitation of vascular endothelial growth factor mRNA splice variants. J Vasc Res 36: 133-138, 1999.

10. Barylski M, Kowalczyk E, Banach M, Ciecwierz J, Pawlicki L and Kowalski J: Plasma total antioxidant activity in comparison with plasma NO and VEGF levels in patients with metabolic syndrome. Angiology 60: 87-92, 2009.

11. Siervo M, Ruggiero D, Sorice R, Nutile T, Aversano M, Stephan BC and Ciullo M: Angiogenesis and biomarkers of cardiovascular risk in adults with metabolic syndrome. J Intern Med 268: 338-347, 2010.

12. Siervo M, Ruggiero D, Sorice R, Nutile T, Aversano M, Iafusco M, Vetrano F, Wells JC, Stephan BC and Ciullo M: Body mass index is directly associated with biomarkers of angiogenesis and inflammation in children and adolescents. Nutrition 28: 262-266, 2012.

13. Siervo M, Tomatis V, Stephan BC, Feelisch M and Bluck LJ: VEGF is indirectly associated with NO production and acutely increases in response to hyperglycaemia(1). Eur J Clin Invest 42: 967-973, 2012.

14. Wada H, Satoh N, Kitaoka S, et al: Soluble VEGF receptor-2 is increased in sera of subjects with metabolic syndrome in association with insulin resistance. Atherosclerosis 208: 512-517, 2010.

15. Petrovič D, Verhovec R, Globocnik Petrovic M, Osredkar J and Peterlin B: Association of vascular endothelial growth factor gene polymorphism with myocardial infarction in patients with type 2 diabetes. Cardiology 107: 291-295, 2007.

16. Awata T, Inoue K, Kurihara S, Ohkubo T, Watanabe M, Inukai K, Inoue I and Katayama S: A common polymorphism in the 5 -untranslated region of the VEGF gene is associated with diabetic retinopathy in type 2 diabetes. Diabetes 51: 1635-1639, 2002.

17. Inoue M, Itoh H, Ueda M, et al: Vascular endothelial growth factor (VEGF) expression in human coronary atherosclerotic lesions: Possible pathophysiological significance of VEGF in progression of atherosclerosis. Circulation 98: 2108-2116, 1998.

18. Watson CJ, Webb NJA, Bottomley MJ and Brenchley PEC: Identification of polymorphisms within the vascular endothelial growth factor (VEGF) gene: Correlation with variation in VEGF protein production. Cytokine 12: 1232-1235, 2000.

19. Renner W, Kotschan S, Hoffmann C, Obermayer-Pietsch B and Pilger E: A common $936 \mathrm{C} / \mathrm{T}$ mutation in the gene for vascular endothelial growth factor is associated with vascular endothelial growth factor plasma levels. J Vasc Res 37: 443-448, 2000.

20. Krippl P, Langsenlehner U, Renner W, Yazdani-Biuki B, Wolf G, Wascher TC, Paulweber B, Haas J and Samonigg H: A common $936 \mathrm{C} / \mathrm{T}$ gene polymorphism of vascular endothelial growth factor is associated with decreased breast cancer risk. Int J Cancer 106: 468-471, 2003.

21. van der Meer P, De Boer RA, White HL, van der Steege G, Hall AS, Voors AA and van Veldhuisen DJ: The VEGF +405 CC promoter polymorphism is associated with an impaired prognosis in patients with chronic heart failure: A MERIT-HF substudy. J Card Fail 11: 279-284, 2005

22. Ray D, Mishra M, Ralph S, Read I, Davies R and Brenchley P: Association of the VEGF gene with proliferative diabetic retinopathy but not proteinuria in diabetes. Diabetes 53: 861-864, 2004.

23. Douvaras P, Antonatos DG, Kekou K, Patsilinakos S, Chouliaras G, Christou A, Andrikou A and Kanavakis E: Association of VEGF gene polymorphisms with the development of heart failure in patients after myocardial infarction. Cardiology 114: 11-18, 2009.
24. Kim OJ, Hong SH, Oh SH, Kim TG, Min KT, Oh D and Kim NK: Association between VEGF polymorphisms and homocysteine levels in patients with ischemic stroke and silent brain infarction. Stroke 42: 2393-2402, 2011

25. Lin TH, Su HM, Wang CL, Voon WC, Shin SJ, Lai WT and Sheu SH: Vascular endothelial growth factor polymorphisms and extent of coronary atherosclerosis in Chinese population with advanced coronary artery disease. Am J Hypertens 23: 960-966, 2010.

26. Lin TH, Wang CL, Su HM, Hsu PC, Juo SH, Voon WC, Shin SJ, Lai WT and Sheu SH: Functional vascular endothelial growth factor gene polymorphisms and diabetes: Effect on coronary collaterals in patients with significant coronary artery disease. Clin Chim Acta 411: 1688-1693, 2010.

27. Wang E, Wang Z, Liu S, et al: Polymorphisms of VEGF, TGF $\beta 1$, TGF $\beta$ R2 and conotruncal heart defects in a Chinese population. Mol Biol Rep 41: 1763-1770, 2014.

28. Grundy SM, Cleeman JI, Daniels SR, et al: Diagnosis and management of the metabolic syndrome: an American Heart Association/National Heart, Lung, and Blood Institute Scientific Statement. Circulation 112: 2735-2752, 2005.

29. Szaflik JP, Wysocki T, Kowalski M, Majsterek I, Borucka AI, Blasiak J and Szaflik J: An association between vascular endothelial growth factor gene promoter polymorphisms and diabetic retinopathy. Graefes Arch Clin Exp Ophthalmol 246: 39-43, 2008.

30. Suganthalakshmi B, Anand R, Kim R, Mahalakshmi R, Karthikprakash S, Namperumalsamy $P$ and Sundaresan P: Association of VEGF and eNOS gene polymorphisms in type 2 diabetic retinopathy. Mol Vis 12: 336-341, 2006.

31. Qiu M, Xiong W, Liao H and Li F: VEGF -634G $>$ C polymorphism and diabetic retinopathy risk: A meta-analysis. Gene 518: 310-315, 2013.

32. Kariyazono H, Ohno T, Khajoee V, Ihara K, Kusuhara K, Kinukawa N, Mizuno Y and Hara T: Association of vascular endothelial growth factor (VEGF) and VEGF receptor gene polymorphisms with coronary artery lesions of Kawasaki disease. Pediatr Res 56: 953-959, 2004.

33. Moradzadegan A, Vaisi-Raygani A, Nikzamir A and Rahimi Z: Angiotensin converting enzyme insertion/deletion (I/D) (rs4646994) and Vegf polymorphism $(+405 \mathrm{G} / \mathrm{C} ; \mathrm{rs} 2010963)$ in type II diabetic patients: Association with the risk of coronary artery disease. J Renin Angiotensin Aldosterone Syst 0: 1-9, 2014.

34. BledaS, De Haro J, Varela C, Esparza L, De Maturana IL and Acin F: Impact of VEGF polymorphisms on the severity of peripheral artery disease in diabetic patients. Growth Factors 30: 277-282, 2012.

35. Nikzamir A, Esteghamati A, Hammedian AA and Mahmoudi T: The role of vascular endothelial growth factor $+405 \mathrm{G} / \mathrm{C}$ polymorphism and albuminuria in patients with type 2 diabetes mellitus. Mol Biol Rep 39: 881-886, 2012.

36. Petrovic MG, Korosec P, Kosnik M, Osredkar J, Hawlina M, Peterlin B and Petrovič D: Local and genetic determinants of vascular endothelial growth factor expression in advanced proliferative diabetic retinopathy. Mol Vis 14: 1382-1387, 2008.

37. Nakamura S, Iwasaki N, Funatsu H, Kitano S and Iwamoto Y: Impact of variants in the VEGF gene on progression of proliferative diabetic retinopathy. Graefes Arch Clin Exp Ophthalmol 247: 21-26, 2009

38. Uthra S, Raman R, Mukesh BN, et al: Association of VEGF gene polymorphisms with diabetic retinopathy in a south Indian cohort. Ophthalmic Genet 29: 11-15, 2008.

39. Rodríguez-Rodríguez L, García-Bermúdez M, González-Juanatey C, Vazquez-Rodriguez TR, Miranda-Filloy JA, Fernández-Gutierrez B, Llorca J, Martín J and González-Gay MA: Vascular endothelial growth factor A and cardiovascular disease in rheumatoid arthritis patients. Tissue Antigens 77: 291-297, 2011.

40. Kangas-Kontio T, Tapanainen JM, Huikuri H, Savolainen ER Päivänsalo M, Kauma H, Kesäniemi YA, Savolainen MJ and Kakko S: Variation in the vascular endothelial growth factor gene, carotid intima-media thickness and the risk of acute myocardial infarction. Scand J Clin Lab Invest 69: 335-343, 2009.

41. Howell WM, Ali S, Rose-Zerilli MJ and Ye S: VEGF polymorphisms and severity of atherosclerosis. J Med Genet 42: 485-490, 2005.

42. Song GG, Kim JH and Lee YH: Vascular endothelial growth factor gene polymorphisms and vasculitis susceptibility: A meta-analysis. Hum Immunol 75: 541-548, 2014. 
43. Muniz JJ, Izidoro-Toledo TC, Metzger IF, Sandrim VC and Tanus-Santos JE: Interethnic differences in the distribution of clinically relevant vascular endothelial growth factor genetic polymorphisms. DNA Cell Biol 28: 567-572, 2009.

44. Sandhofer A, Tatarczyk T, Kirchmair R, Iglseder B, Paulweber B, Patsch JR and Schratzberger P: Are plasma VEGF and its soluble receptor sFlt-1 atherogenic risk factors? Cross-sectional data from the SAPHIR study. Atherosclerosis 206: 265-269, 2009.

45. Huez I, Bornes S, Bresson D, Créancier L and Prats H: New vascular endothelial growth factor isoform generated by internal ribosome entry site-driven CUG translation initiation. Mol Endocrinol 15: 2197-2210, 2001.
46. Stevens A, Soden J, Brenchley PE, Ralph S and Ray DW: Haplotype analysis of the polymorphic human vascular endothelial growth factor gene promoter. Cancer Res 63: 812-816, 2003.

47. Strauss E, Waliszewski K, Oszkinis G and Staniszewski R: Polymorphisms of genes involved in the hypoxia signaling pathway and the development of abdominal aortic aneurysms or large-artery atherosclerosis. J Vasc Surg: Mar 20, 2014 (Epub ahead of print). 